\title{
Arsenic contamination in the deep tube wells of Kathmandu Valley, Nepal
}

\author{
S.M. Shrestha*, S.P. Wagley, S. Parajuli, U. KC, A. KC \\ Central Department of Environmental Science, Tribhuvan University, Kathmandu, Nepal
}

\begin{abstract}
A study was conducted at 13 different areas of Kathmandu Valley to know the status of arsenic in deep tube wells in post monsoon and winter in 2009 and 2010. The depth of the deep tube wells ranged from $75 \mathrm{~m}$ to $304 \mathrm{~m}$. The study was also carried out to know the correlations between depths of the deep tube wells and arsenic concentration. The collected samples were analyzed as per standard method using spectrophotometer. The correlations of arsenic concentration in different season (post monsoon and winter) were also studied. $92.31 \%$ of deep tube wells in post monsoon and winter exceeded permissible values of World Health Organization guideline value $0.01 \mathrm{mg} / \mathrm{L}$ for drinking water but $38.46 \%$ deep tube wells in post monsoon and $46.15 \%$ of deep tube wells in winter exceeded permissible values of Nepal Drinking Water Standard of $0.05 \mathrm{mg} / \mathrm{L}$. There was strong positive correlation in arsenic concentration between post monsoon and winter $(r=0.94, p<0.001)$. There was weak but positive correlation between arsenic concentration and depth of deep tube wells in winter $(r=0.23$, $p=0.451)$. There was very weak correlations between arsenic concentration and depth of deep tube wells in post monsoon $(r=0.055, p=0.859)$. The trend distribution maps were generated for arsenic in post monsoon and winter.
\end{abstract}

Key words: Correlation, Depth, GIS, Post monsoon, Winter

\section{Introduction}

Arsenic contamination of drinking water is one of the major problems in the world. Arsenic poses health risks and health problems. Arsenic contamination of groundwater has been reported from many countries including Bangladesh, India, Vietnam, Argentina, China and USA (Hossain, 2006). Arsenic contaminations of ground water also have been reported in Nepal. Arsenic concentration in the groundwater of Kathmandu Valley, Nepal is one of the major concerns while assessing groundwater quality. The permissible limit for arsenic in drinking water as recommended by World Health organization (WHO) is $0.01 \mathrm{mg} / \mathrm{L}$ (WHO, 2008). Nepal has also set drinking water quality standard of arsenic $0.05 \mathrm{mg} / \mathrm{L}$ (GoN/MPP, 2006).

More than $50 \%$ of the world's population depends on groundwater for drinking (Fry, 2005). For many rural and small communities, groundwater is the only source of drinking water (Hani, 1990). Since groundwater moves through rocks and subsurface soil, it has a lot of opportunity to dissolve substances as it moves. Furthermore, they are

*Corresponding author, email address: sshrestha@cdes.edu.np widely distributed as anthropogenic pollutants (Rangsivek \& Jekel, 2005).

The present permanent population of the Valley water supply service area is estimated at over 2.1 million with a water demand of 195 MLD. The total water production in wet and dry seasons is about 140 MLD and 100 MLD respectively. The ground water is depleting due to over extraction and surface water catchments are becoming degraded (ADB/KUKL, 2010).

Over the last few decades, groundwater has become one of the major water resources of Kathmandu Valley. In Kathmandu Valley, groundwater was first exploited for water supply in1970. Development of groundwater resources began in earliest in 1984. In 1987, the groundwater extraction rate from Nepal Water Supply Corporation (NWSC); wells had nearly quadrupled the 1984 extraction. It is important to note that about $45 \%$ of the total municipal water supply is fulfilled by groundwater resources in Kathmandu Valley. Additional industrial use of the municipal supply is not permitted for new major industries; therefore, groundwater is only the source of the water (AI, 2002). 
Kathmandu is a close basin. The clayey aquifer and the deep aquifers are rich in organic matter and are in reduced condition evident from low oxidation reduction potential (mostly negative). These aquifer-pockets with organic matter activities have potential for the release of arsenic. The redox environment of the deep aquifers of the Kathmandu Basin could have changing, probably due to continuous pumping of water and gases. This could lead the condition favorable for arsenic release (Gurung, 2007).

Arsenic concentrations have been reported in groundwater of Kathmandu Valley. Vulnerability of arsenic in deep tube wells in Kathmandu Valley is a very critical issue due to its negative impact on health as a high percentage of water demand in the valley is met through ground water resources A study carried out by Maharjan et al. (2009) revealed that water samples from 149 shallow tube wells and 87 dug wells were tested for arsenic concentration in pre-monsoon and 122 deep tube wells were tested in pre-monsoon and monsoon. A study carried out in 41 shallow tube wells has confirmed existence of arsenic in shallow tube wells of Kathmandu Valley though in low level (Shrestha et al., 2010).

Groundwater survey of Kathmandu Valley reported the presence of arsenic and the concentrations were below
WHO (1993) guidelines values (Jha et al., 1997). A study carried out by Amatya (2002) found that the arsenic concentration of some samples exceeded the national guideline value. Similar study carried out by JICA/ENPHO (2005) revealed that the ground water resources of Kathmandu Valley are highly vulnerable to arsenic contamination, particularly in deep aquifers (>200 m) of several samples exceeded $0.200 \mathrm{mg} / \mathrm{L}$. These studies have confirmed the existence of arsenic in ground water of Kathmandu Valley.

This study examines the concentration of arsenic deep tube wells of Kathmandu Valley. It also establishes correlation between depth of the tube wells and arsenic concentration and correlations between the arsenic concentrations in different seasons (post monsoon and winter). It also evaluates the distribution patterns of arsenic by spatial interpolation techniques in GIS.

The objectives of the study were:

i) to determine concentration of arsenic in deep tube wells of Kathmandu Valley

ii) to show the relationships between depth of the tube wells and arsenic concentration

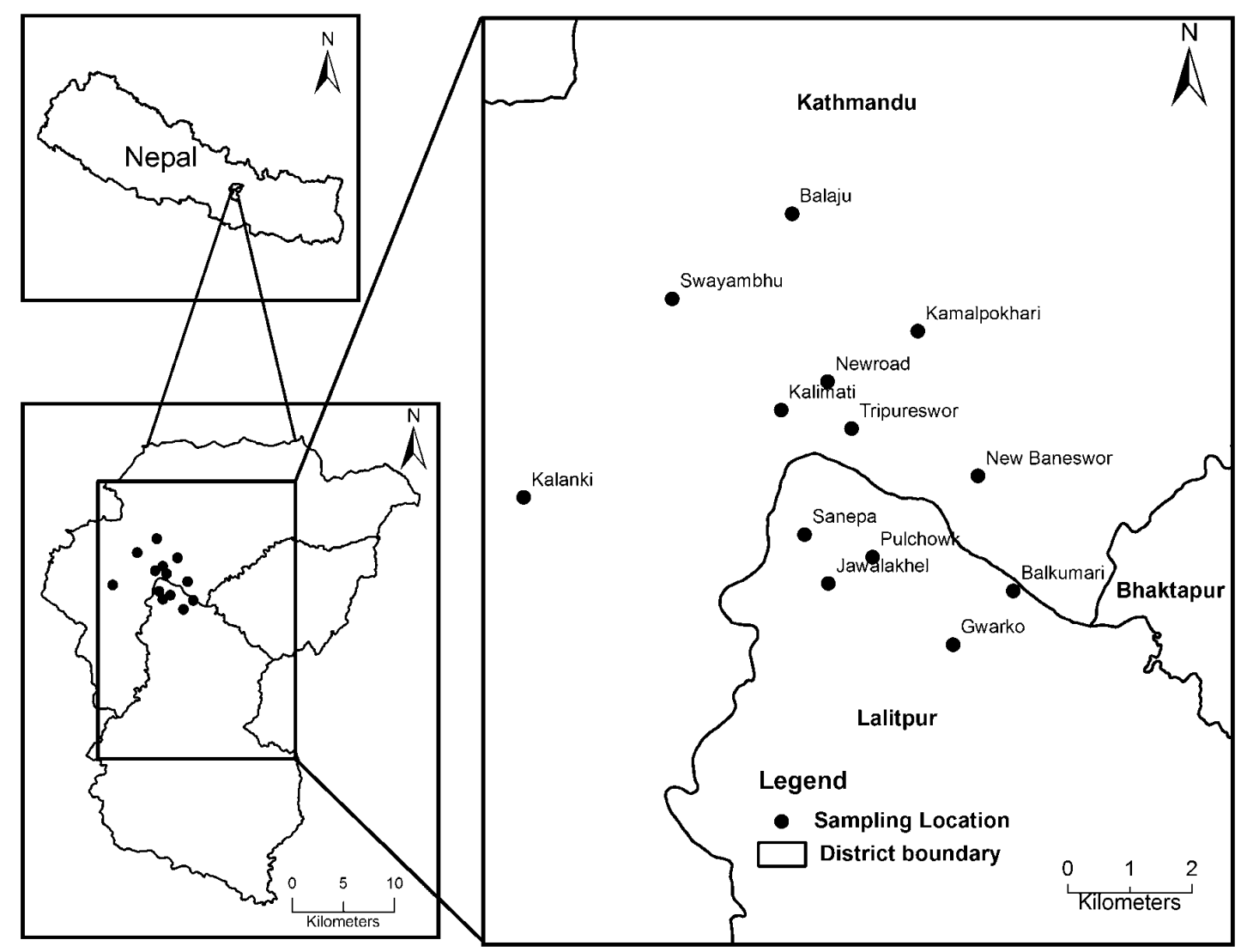

Fig. 1 Study area and sampling location in the study area 
iii) to show the seasonal variation of arsenic concentration in deep tube wells

iv) to evaluate the distribution patterns of arsenic by spatial interpolation techniques in GIS

\section{Materials and Methods Study area}

Kathmandu Valley covers an area of roughly $500 \mathrm{~km}^{2}$ centered on $27^{\circ} 42^{\prime} \mathrm{N}, 85^{\circ} 22^{\prime} \mathrm{E}$. It is located in the central part of Nepal (Fig. 1). The average altitude of the Valley floor is about $1350 \mathrm{~m}$ above sea level and the surrounding hills are about $2800 \mathrm{~m}$ above sea level. The climate of the region is semi tropics, warm and temperate; and annual precipitation is $1639.7 \mathrm{~mm}$ (CBS, 2008). The precipitation is dominated by monsoon rainfall, which lasts for the months of July to September and contributes $80 \%$ of annual precipitation (JICA, 1990).

Kathmandu Valley is small intra-mountain Valley. The Kathmandu Valley occupies an intermontane basin containing up to $500 \mathrm{~m}$ of a thick band of Pliocene-Quaternary fluviolacustrine sediments (Yoshida \& Igarashi, 1984). The deep aquifer system can be divided into three groundwater zones based on hydrogeological considerations. The northern zone, forming the main aquifer, has the upper deposits composed of unconsolidated and highly permeable micaceous quartz and gravel materials. The coarse sediments in the northern part of the Valley represent delta deposits and facies that are influenced by the processes of delta progradation and paleolake fluctuation. In the central zone, the upper deposits are composed of impermeable very thick stiff black clay with peat and lignite bands. Unconsolidated low permeable coarse sediments underlying the clay bed constitute a confined aquifer. The urban cores of Kathmandu and Lalitpur (Patan) are located in this middle region. The formation of the southern part is characterized by a thick impermeable clay and basal gravel of low permeability (Dixit \& Upadhya, 2005; Sakai, 2001).

\section{Water sampling and analysis}

The study was carried out in 13 different areas of Kathmandu and Lalitpur municipalities of Kathmandu Valley (Fig. 1)The study covered the deep tube wells of 75-304 m depth. In each area, 13 households with deep tube wells were chosen to collect the water samples. Groundwater samples from each sampling sites geo-positions were determined using global positioning systems (GPS).

Random sampling technique was used to collect ground water samples. The water samples were taken in post monsoon (month of October 2009) and winter (month of February 2010). A set of samples were collected in the sampling bottles randomly after pumping water for five minutes before sampling to get the representative sample of the tube well. The bottles were labeled with the sample code number. Those samples were preserved and then brought to the laboratory for analysis. The collected samples were analyzed in the laboratory of Central Department of Environmental Science, Tribhuvan University, Kathmandu as per standard method. Silver diethyl dithio carbamate (SDDC) method was used for analysis of arsenic (APHA/AWWA/WEF, 1998). Calibration curve was prepared by using Microsoft Office Excel (2007). The concentrations of the arsenic were computed on the basis of calibration curve. Microsoft Office Excel (2007) was used for statistical analysis.

\section{GIS and spatial analysis}

Nepal adopted Universal Transverse Mercator (UTM) projection for the base mapping of the country with some modifications suited to its shape. This is named as Modified Universal Transverse Mercator Projection (MUTM). So, all the spatial data layers were maintained in a standard Nepalese coordinate system of Modified Universal Transverse Mercator, Central Meridian $84^{\circ}$ Longitude (i.e., MUTM84).

The draft and thematic maps were generated and digitized. Geostatistics are widely used to estimate the spatial variability and distribution of field data with uncertainty (Cressie, 1985). Kriging is one of the geostatistical tools applied to analyze spatial horizontal distribution of field data. Kriging interpolation was applied to analyze spatial horizontal distribution of arsenic in groundwater. The software used for spatial analysis was ArcGis version 9.3.

\section{Results and Discussion}

The arsenic concentration of the deep tube wells of Kathmandu Valley has been measured for post monsoon and winter. The deep tube wells exceeded arsenic concentration $0.05 \mathrm{mg} / \mathrm{L}$ in post monsoon was $38.5 \%$ and $46.2 \%$ in winter. The deep tube well showed arsenic concentration less than $0.01 \mathrm{mg} / \mathrm{L}$ was $7.7 \%$ in both post monsoon and winter. The deep tube wells showed arsenic concentration in between $0.04 \mathrm{mg} / \mathrm{L}$ and $0.05 \mathrm{mg} / \mathrm{L}$ in post monsoon was $15.4 \%$ and $15.4 \%$ in winter (Table 1 ).

Table 1 Arsenic level classification in post monsoon and winter

\begin{tabular}{lcc}
\hline $\begin{array}{l}\text { Arsenic } \\
(\mathrm{mg} / \mathrm{L})\end{array}$ & $\begin{array}{c}\text { Number (\%) tube wells } \\
\text { in post monsoon }\end{array}$ & $\begin{array}{c}\text { Number }(\%) \text { tube wells } \\
\text { in winter }\end{array}$ \\
\hline$<0.01$ & $1(7.7)$ & $1(7.7)$ \\
$0.01-0.05$ & $7(53.8)$ & $6(46.2)$ \\
$>0.05$ & $5(38.5)$ & $6(46.2)$ \\
\hline Total & $\mathbf{1 3 ( 1 0 0 . 0 )}$ & $\mathbf{1 3 ( 1 0 0 . 0 )}$ \\
\hline
\end{tabular}


The highest arsenic concentration was measured in a deep tube well of Gwarko (depth $275 \mathrm{~m}$ ) in winter was $0.105 \mathrm{mg} / \mathrm{L}$ and followed by $0.095 \mathrm{mg} / \mathrm{L}$ in a deep tube well in Kalanki (depth $259 \mathrm{~m}$ ). The concentrations of arsenic in those areas in post monsoon were reduced to $0.065 \mathrm{mg} / \mathrm{L}$ and 0.076 $\mathrm{mg} / \mathrm{L}$, respectively. The lowest arsenic concentration measured in a deep tube well of Jawalakhel (depth $122 \mathrm{~m}$ ) in post monsoon was $0.029 \mathrm{mg} / \mathrm{L}$ and followed by 0.032 $\mathrm{mg} / \mathrm{L}$ in a deep tube well in Pulchowk (depth $219 \mathrm{~m}$ ). The concentrations of arsenic in these areas in winter increased to $0.041 \mathrm{mg} / \mathrm{L}$ and $0.050 \mathrm{mg} / \mathrm{L}$, respectively (Fig. 2).

Mean, median, minimum and maximum arsenic concentration for post monsoon were $0.053 \mathrm{mg} / \mathrm{L}, 0.048$ $\mathrm{mg} / \mathrm{L}, 0.029 \mathrm{mg} / \mathrm{L}$ and $0.090 \mathrm{mg} / \mathrm{L}$, respectively, and for winter were $0.075 \mathrm{mg} / \mathrm{L}, 0.083 \mathrm{mg} / \mathrm{L}, 0.041 \mathrm{mg} / \mathrm{L}$ and 0.105 $\mathrm{mg} / \mathrm{L}$, respectively.

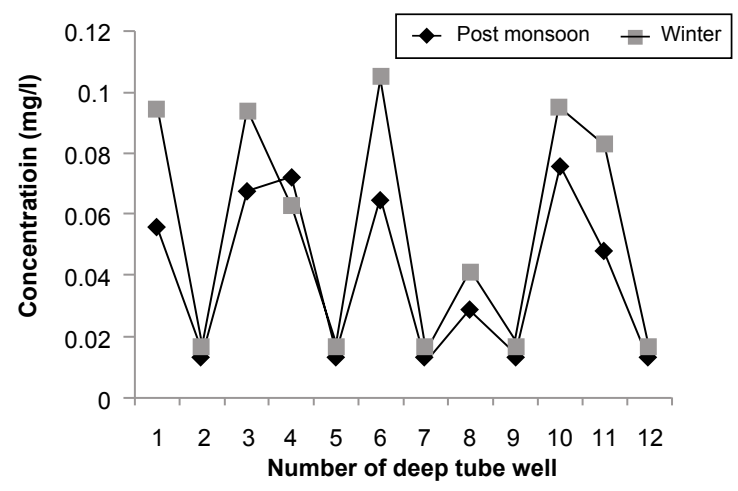

Fig. 2 Arsenic concentrations in post monsoon and winter

Arsenic concentration in $92.30 \%$ tube wells increased from post monsoon to winter and reduced in $7.7 \%$ tube wells. In most of the tube wells the arsenic concentrations measured were higher in winter (Fig. 2).

The depth of the tube wells tested arsenic ranged from 75 to $304 \mathrm{~m}$. The mean and standard deviation (SD) of depth were $219.8 \mathrm{~m}$ and $74.8 \mathrm{~m}$, respectively. It showed weak but positive correlations between arsenic concentration and depth of deep tube wells in winter $(r=0.23, p=0.451)$. Similar results shown by the studies carried out by JICA/ENPHO (2005), Maharjan et al. (2007) and Shrestha et al. (2010). It contradicts with the situation found in the Terai where deeper wells tend to have lower concentration of arsenic. In the Terai Basin, arsenic contamination is greater in the shallow tube wells $(<20 \mathrm{~m})$ than in the deep wells. However, the opposite is the case in the Kathmandu Basin, with the deep tube well water having the higher arsenic concentration up to $0.200 \mathrm{mg} / \mathrm{L}$. The cause of higher arsenic in deep wells is not understood. However, conditions in the deep aquifers in Kathmandu Basin are more reducing (Khatiwada et al., 2002). In more than $200 \mathrm{~m}$, the dilution of arsenic concentration is less significant because the percolation of monsoon water to the depth more than $200 \mathrm{~m}$ is limited. It is due to the contrast geochemistry of groundwater in the shallow and deep aquifers.

Arsenic concentration in $84.62 \%$ tube wells increased from post monsoon to winter and reduced in $7.7 \%$ tube wells. Higher arsenic concentration in winter compared to that of post monsoon. Arsenic concentration was not detected in one tube well. Mean, median, and maximum arsenic concentration for post monsoon were $0.037 \mathrm{mg} / \mathrm{L}, 0.029$ $\mathrm{mg} / \mathrm{L}$, and $0.076 \mathrm{mg} / \mathrm{L}$, respectively, and for winter were $0.051 \mathrm{mg} / \mathrm{L}, 0.041 \mathrm{mg} / \mathrm{L}$ and $0.105 \mathrm{mg} / \mathrm{L}$, respectively. Arsenic concentration in $7.7 \%$ of tube wells were less than 0.01 $\mathrm{mg} / \mathrm{L}$. In most of the tube wells the arsenic concentrations measured were higher in winter (Fig. 2). It showed strong positive correlation between arsenic concentration in post monsoon and winter $(r=0.94, p<0.001)$, which infers similar distribution of arsenic in both seasons. Arsenic concentrations were insignificantly varied between seasonal groundwater samples (Fig. 2).

In post monsoon and winter $92.31 \%$ of tube wells exceeded permissible values of World Health Organization guideline value of $0.01 \mathrm{mg} / \mathrm{L}$ for drinking water (WHO, 2008). In post monsoon $38.5 \%$ and in winter $46.2 \%$ exceeded the permissible values of Nepal Drinking Water Standard of 0.05 mg/L (GoN/MPP, 2006).

This study has confirmed the existence to arsenic in deep aquifers of Kathmandu Valley. Thus, understanding of the arsenic-release in the Kathmandu Valley is important. Two mechanisms of arsenic release are probable in the groundwater of the valley. First is the mobilization of arsenic due to the change of redox condition. Arsenic mobilizition is high in the reducing conditions (Carbonell-Barrachina et al., 1999; McArThur et al., 2004; Smedley \& Kinniburgh, 2002). The groundwater displays clear redox gradient between shallow and deep aquifers as indicated by the diminishing trend of ORP downward from shallow to deeper depth. Khatiwada et al. (2002) reported negative ORP (-195 $\mathrm{mV}$ ) in deep aquifers showing highly reduced environment. Arsenic concentrations in the sediments of Kathmandu Valley averaged $8 \mathrm{mg} / \mathrm{kg}$ (ramging 3-25 mg/kg) similar to the general level seen in the modern unconsolidated sediments, typically 5-10 mg/kg (Gurung et al., 2007; Smedley \& Kinniburgh, 2002).

Though the study showed positive correlation between arsenic concentration and depth of tube wells in winter, it showed very weak positive correlations between depth of the tube wells and arsenic concentration in monsoon $(r=0.055, p=0.859)$ and $p$-value suggest there is an insignificant correlation. 
A geospatial analysis of arsenic was performed to attempt to identify areas in the sampled regions of increased contamination (hotspots). Geospatial analysis has become increasingly important when examining spatial trends. A GISbased kriging technique was utilized to interpolate contamination estimates between sampling locations. The spatial distributions of maps were analyzed using kriging method. Semivariogram analysis for kriging interpolation showed that arsenic concentrations in post monsoon and winter were best fitted for exponential model. In kriging analysis, areas of color indicate areas where one would expect to see similar concentration of the element of interest. The geospatial analysis revealed that several areas of the state tend to have higher concentrations of metals in both seasons.

The geospatial trends in Kalanki, Sanepa, Jawalakhel, Balkumari and Gwarko which lies in the central ground water zone of the study area showed high arsenic concentration in the post monsoon and winter (Figs. 3, 4). Likewise, Tripureswor, New Road, Kalimati and New Baneswor also showed relatively higher concentration of arsenic. The thick layers of the Kalimati Formation in these areas with fine grained sediments would have influenced in increase of arsenic concentration. Similarly, as this aquifer is of nonrechargeable type (JICA, 1990); the deep aquifer appears to have higher arsenic concentration. The studies carried out by Fujii and Sakai (2001) have indicated that the fluviolacustrine sediment in the Kathmandu Valley is rich in organic matter, especially the clayey sediments of central part of the valley, which could have enhanced the arsenic mobilization. All these features demonstrate that the deep aquifers are under reduced arsenic mobilization is high in the reducing conditions though not all reducing water contains arsenic. The spatial analysis revealed that the concentration of arsenic was low in Swayambhu and Kamalpokhari which are in Tistung and Gokarn Formations, respectively (Figs. 3, 4). This may be attributed to coarse region with grained sediments in these Formations.

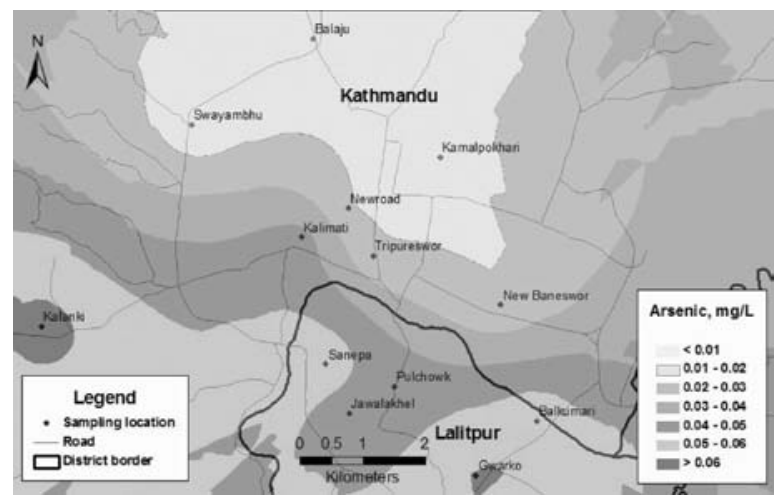

Fig. 3 Spatial distribution map of arsenic in post monsoon

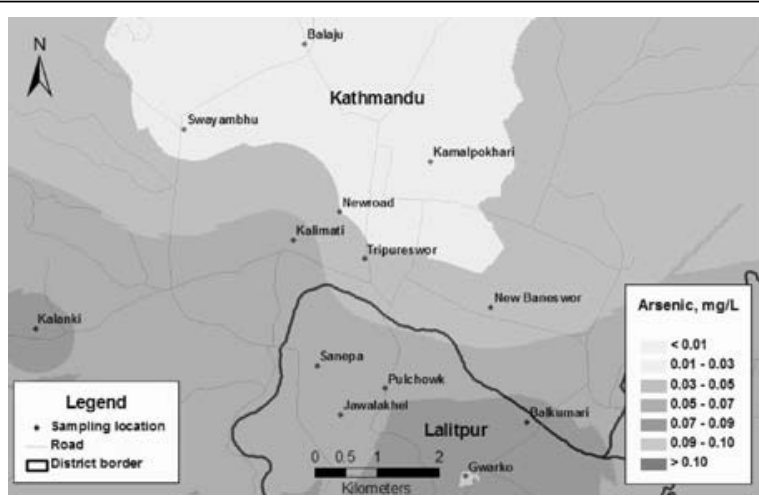

Fig. 4 Spatial distribution map of arsenic in winter

\section{Conclusion}

This study has confirmed the existence higher levels of arsenic in deep tube wells of Kathmandu Valley. The highest arsenic concentration measured in winter was $0.105 \mathrm{mg} / \mathrm{L}$ and $0.076 \mathrm{mg} / \mathrm{L}$ in post monsoon. The study showed strong positive correlation between arsenic concentration in post monsoon and winter, suggesting similar distribution of arsenic. It also showed weak but positive correlation between arsenic concentration and depth of deep tube wells in winter. GIS and geospatial analysis were used to generate distribution maps for arsenic. Kriging method was selected for interpolation, which satisfy statistically optimal and unbiased prediction. The high concentration of arsenic in some parts of study area is attributed to the groundwater geochemistry in the study area.

\section{Acknowledgements}

The authors are very much grateful to all the staffs and faculties of Central Department of Environmental Science, Tribhuvan University, Kathmandu, Nepal.

\section{References}

ADB/KUKL (2010). Kathmandu Valley water supply and wastewater system improvement. Project feasibility study report. Kathmandu, Asian Development Bank and Kathmandu Upatyaka Khanepani Limited.

AI (2002). Optimizing water use in Kathmandu Valley project. Inception report. Acres International, ARCADSI Euroconsult Land and Water Product Management Group, Eastconsult (P) Ltd., Water Asia (P) Ltd.

Amatya, A. (2002). Arsenic in groundwater of alluvial aquifers in Nepal, extent of contamination, genesis and aspects of remediation in the districts of Nawalparasi and Kathmandu (Unpublished Master's dissertation). TRITA-LWR, Department Land and Water Resource Engineering, Stockholm. 
APHA/AWWA/WEF (1998). Standard methods for the examination of water and wastewater (20th Ed.). Washington D.C., American Public Health Association, American Water Works Association, Water Environment Federation.

Carbonell-Barrachina, A.A., Jugsujinda, A., Burlo, F., Delaune, R.D., \& Patrick, W. H. (1999). Arsenic chemistry in municipal sewage as affected by redox potential and $\mathrm{pH}$. Water Research, 34, 216-224.

CBS (2008). Environment Statistics of Nepal. Kathmandu, Central Bureau of Statistics.

Cressie, N. (1985). Fitting variogram models by weighted least squares. Mathematical Geosciences, 17, 563-586.

Dixit, A., \& Upadhya, M. (2005). Augmenting Groundwater in Kathmandu Valley: Challenges and possibilities. Report to Nepal Water Conservation Foundation, Kathmandu.

Fry, A. (2005). Water facts and trends, World Business Council for Sustainable Development: 16.

Fujii, R., \& Sakai, H. (2001). Palynological study on the drilled sediments from the Kathmandu Basin and its paleoclimatic significances. Journal of Nepal Geological Society, 25, 53-61.

GoN/MPP (2006). National drinking water quality standards. In Nepal Gazette (B.S. 2063/03/12). Kathmandu, Ministry of Physical Planning, Government of Nepal.

Gurung, J.K. (2007). Geochemical studies of sediments and water and implications for mobilization of arsenic into groundwater in Nepal and Japan (Unpublished doctoral thesis). Shimane University, Japan.

Gurung, J.K., Ishiga, H., Khadka, M.S., \& Shrestha, N.R. (2007). The geochemical study of fluvio-lacustrine aquifers in the Kathmandu Basin (Nepal) and the implications for mobilization of arsenic. Environmental Geology, 52, 503-517.

Hani, H. (1990). The analysis of inorganic and organic pollutants in soil with special to their bioavailability. International Journal of Environnemental Analytical Chemistry, 39, 197-308.

Hossain, M.F. (2006). Arsenic contamination in Bangladeshan overview. Agriculture Ecosystems and Environment, 113, 1-16.

Jha, M.G., Khadka, M.S., Shrestha, M.P., Regmi, S., Bauld, J., \& Jacobson, G. (1997). The assessment of groundwater pollution in Kathmandu, Nepal. Report on joint NepalAustralia Project, 1995-96. Kathmandu, Groundwater Resources Development Board, Department of Irrigation, GoN/Australian-Geological Survey Organization.
JICA (1990). Groundwater management project in the Kathmandu Valley. Final report to Nepal Water Supply Corporation. Japan International Cooperation Agency, Kathmandu.

JICA/ENPHO (2005). Arsenic vulnerability in groundwater resources in Katbmandu Valley (Report). Kathmandu, Japan International Cooperation Agency/Environment and Public Health Organization.

Khatiwada, N.R., Takizawa, S., Tran, T.V.N., \& Inoue, M. (2002). Groundwater contamination assessment for sustainable water supply in Kathmandu Valley, Nepal. Water Science Technology, 46, 147-154.

Maharjan, M., Shrestha, B.R., Shrestha, K.B., Shrestha, R.R., Khadka, R.R., Shrestha, S.D., Kafle, B., \& Ishihara, H. (2009). Arsenic contamination in groundwater resources in Kathmandu Valley. In S.Takizawa, F. Kurishi, \& H. Satoh (Eds.), Southeast Asian Water Environment 3. IWA Publishing, UK.

McArthur, J.M., Banerjee, D.M., Hudson-Edwards, K.A., Mishra, R., Purohit, R., Ravenscroft, P., Cronin, A., Howarth, R.J., Chatterjee, A., Talukder, T., Lowry D., Houghton, S., \& Chada, D.K. (2004). Natural organic matter in sedimentary basins and its relation to arsenic in anoxic groundwater: the example of West Bengal and its worldwide implications. Applied Geochemistry, 19,1255-1293.

Rangsivek, R., \& Jekel, M.R. (2005). Removal of dissolved metals by Zero- Valent Iron (ZVI). Water Research, 39, 4153-4163.

Sakai, T. (2001). Small amplitude lake-level fluctuations recorded in aggrading deltaic of the upper Pleistocene Thimi and Gokarna formations, Kathmandu Valley, Nepal. Journal of Nepal Geological Society, 25, 43-52.

Shrestha, S.M., Dhakal, P., Khadka, M., \& Shrestha, S. (2010, June). Status of arsenic in groundwater of Kathmandu Valley, Nepal. Proceedings of the First National Youth Conference on Environment. Kathmandu, Himalayan Alliance for Climate Change.

Smedley, P.L., \& Kinniburgh, D.G. (2002). A review of the source, behavior and distribution of arsenic in natural waters. Applied Geochemistry, 17, 517-568.

WHO (2008). Guidelines for drinking-water quality. Geneva, World Health Organization.

Yoshida, M., \& Igarashi, Y. (1984). Neogene to quaternary lacustrine sediment in the Kathmandu Valley, Nepal. Journal of Nepal Geological Society, 4, 73-100. 